Original article

\title{
Hemodynamic Changes Caused by Exposure of Animals with Acute Immobilization Stress to Continuous Terahertz Radiation with Frequencies equal to Absorption and Emission Frequencies of Nitrogen Oxide and Atmospheric Oxygen
}

\author{
Vyacheslav F. Kirichuk, Vitaly V. Velikanov, Tatyana S. Velikanova, Olga N. Antipova, Evgeny V. Andronov, \\ Alexey N. Ivanov, Svetlana S. Parshina, Natalia E. Babichenko, Tatyana S. Kiriyazi, Elena V. Ponukalina, \\ Irina V. Smyshlyaeva, Liliana K. Tokaeva, Alexander A. Tsymbal
}

Department of Physiology n.a. I.A. Chuevsky, Saratov State Medical University n.a. V.I. Razumovsky, Saratov, Russia

Received 10 September 2012, Accepted 12 October 2012.

C 2012, Kirichuk V.F., Velikanov V.V., Velikanova T.S., Antipova O.N., Andronov E.V., Ivanov A.N., Parshina S.S., Babichenko N.E., Kiriyazi T.S., Ponukalina E.V., Smyshlyaeva I.V., Tokaeva L.K., Tsymbal A.A.

(C) 2012, Russian Open Medical Journal

\begin{abstract}
The aim was to study the effects of exposure of albino rats to continuous terahertz radiation with frequencies equal to absorption and emission frequencies of nitrogen oxide $(150.176-150.664 \mathrm{GHz})$ and atmospheric oxygen $(129.0 \pm 0.75 \mathrm{GHz})$ during their immobilization stress on their blood flow rate. Methods - The group of 120 male non-pedigree albino rats with average weight of $180-220$ $\mathrm{g}$ was chosen as a test subject. Simulation of hemodynamic disorders was achieved by incurring active immobilization stress. All rats were exposed to electromagnetic terahertz radiation equal to absorption and emission frequencies of nitrogen oxide $(150.176-150.664 \mathrm{GHz})$ and atmospheric oxygen $(129.0 \pm 0.75 \mathrm{GHz})$ for 5,15 and 30 minutes. Results - Experimental simulation of hemodynamic disorders during acute immobilization stress has shown that exposure to continuous terahertz radiation with frequencies equal to absorption and emission frequencies of nitrogen oxide $(150.176-150.664 \mathrm{GHz})$ and atmospheric oxygen $(129.0 \pm 0.75 \mathrm{GHz})$ for 5,15 and 30 minutes allows to revert post-stress hemodynamic changes in great vessels. Conclusion - This allows using terahertz electromagnetic radiation with frequencies equal to absorption and emission frequencies of nitrogen oxide (150.176-150.664 GHz) and atmospheric oxygen $(129.0 \pm 0.75 \mathrm{GHz})$ to treat hemodynamic disorders accompanying some of pathologic diseases.
\end{abstract}

Keywords: hemodynamics, linear blood flow rate, terahertz waves, nitrogen oxide, atmospheric oxygen.

Cite as Kirichuk VF, Velikanov VV, Velikanova TS, Antipova ON, Andronov EV, Ivanov AN, Parshina SS, Babichenko NE, Kiriyazi TS, Ponukalina EV, Smyshlyaeva IV, Tokaeva LK, Tsymbal AA. Hemodynamic Changes Caused by Exposure of Animals with Acute Immobilization Stress to Continuous Terahertz Radiation with Frequencies equal to Absorption and Emission Frequencies of Nitrogen Oxide and Atmospheric Oxygen. Russian Open Medical Journal 2012; 1: 0303.

Correspondence to Prof. Vyacheslav F. Kirichuk. Address: Department of Physiology n.a. I.A. Chuevsky, Saratov State Medical University n.a. V.I. Razumovsky, 112, Bolshaya Kazachiya str., Saratov, 410012, Russia. E-mail: normal@yandex.ru.

\section{Introduction}

Hemodynamic disorders can be treated by a wide range of vasodilating agents. However, the optimal results are rather hard to achieve: there is always a risk of undesirable adverse effects and counter indications limiting application of these agents.

That's why, nowadays, development of new drug-free methods of hemodynamic disorder treatment is a subject of intense study. One of such methods is application of low-intensive millimeter and submillimeter radiation [1-4].

In recent years, a new branch of information therapy has emerged - terahertz therapy [5]. Terahertz frequency band makes for an interesting research subject because molecular absorption and emission spectra (MAES) of various cell metabolites (NO, CO, active forms of oxygen etc.) belong to this band [6].

of the above mentioned test subjects for electromagnetic radiation effect study, the most interesting are frequencies of absorption and emission spectra of nitrogen oxide (150.176-
$150.664 \mathrm{GHz})$ and atmospheric oxygen $(129.0 \pm 0.75 \mathrm{GHz})$ as there is evidence of positive effect of the said frequencies energy deposition on rheological properties of blood and platelet functional activity $[7,8]$, blood clotting and fibrinolytic activity [8], blood gas and electrolyte concentration [10], lipid peroxidation and antioxidative activity $[11,12]$, functional status of thyroid body [13], primary indices of metabolic status [14], concentration of adrenocorticotropic hormone in blood [15], receptor system of formed blood elements [16], state of vascular endothelium [17] and microcirculation [18].

The lack of data on physiological effects of exposure of albino rats to electromagnetic terahertz radiation with frequencies equal to absorption and emission frequencies of nitrogen oxide (150.176-150.664 GHz) and atmospheric oxygen $(129.0 \pm 0.75 \mathrm{GHz})$ during their immobilization stress leading to disrupted blood flow velocity served as a primary reason for studying various modes of terahertz radiation with the said frequencies. 
Physiology and Pathophysiology

Table 1. . Hemodynamic parameters of abdominal aorta blood flow in control group's rats, rats with acute immobilization stress, and rats exposed to terahertz $150.176-150.664 \mathrm{GHz}$ radiation under immobilization stress

\begin{tabular}{|c|c|c|c|c|c|}
\hline \multirow{2}{*}{ Parameters } & \multirow{2}{*}{ Control group } & \multirow{2}{*}{ Immobilization stress } & \multicolumn{3}{|c|}{ Time of radiation exposition under stress } \\
\hline & & & 5 minutes & 15 minutes & 30 minutes \\
\hline Vam, $\mathrm{cm} / \mathrm{s}$ & $15.2(14.04-15.8)$ & $\begin{array}{c}17.7(17.17-20.6) \\
p_{1}=0.000015\end{array}$ & $\begin{array}{c}16.19(15.37-17.64) \\
p_{1}=0.110288 \\
p_{2}=0.003943\end{array}$ & $\begin{array}{c}15.09(14.25-15.86) \\
p_{1}=0.950390 \\
p_{2}=0.000005\end{array}$ & $\begin{array}{c}14.77(14.16-15.74) \\
p_{1}=0.693551 \\
p_{2}=0.000003\end{array}$ \\
\hline Vas, $\mathrm{cm} / \mathrm{s}$ & $34.5(32.93-37.64)$ & $\begin{array}{c}40.56(35.28-43.91) \\
p_{1}=0.007941\end{array}$ & $\begin{array}{c}34.45(30.58-38.12) \\
p_{1}=0.917411 \\
p_{1}=0.021334\end{array}$ & $\begin{array}{c}34.60(31.36-36.07) \\
\mathrm{p}_{1}=0.533833 \\
\mathrm{p}_{2}=0.005114\end{array}$ & $\begin{array}{c}34.34(31.36-38.42) \\
p_{1}=0.633364 \\
p_{2}=0.003454\end{array}$ \\
\hline Vad, cm/s & $3.13(0.78-4.7)$ & $\begin{array}{c}3.92(3.13-6.27) \\
p_{1}=0.038089\end{array}$ & $\begin{array}{c}2.45(0.78-3.92) \\
p_{1}=0.708923 \\
p_{2}=0.010122\end{array}$ & $\begin{array}{c}1.46(0.00-3.13) \\
p_{1}=0.105740 \\
p_{2}=0.000724\end{array}$ & $\begin{array}{c}2.50(1.56-3.92) \\
p_{1}=0.724416 \\
p_{2}=0.012093\end{array}$ \\
\hline $\mathrm{PG}, \mathrm{mmHg}$ & $0.46(0.4-0.54)$ & $\begin{array}{c}0.64(0.49-0.73) \\
p_{1}=0.008443\end{array}$ & $\begin{array}{c}0.46(0.36-0.57) \\
p_{1}=0.900972 \\
p_{2}=0.018067\end{array}$ & $\begin{array}{c}0.45(0.38-0.49) \\
p_{1}=0.383733 \\
p_{2}=0.042101\end{array}$ & $\begin{array}{c}0.48(0.38-0.57) \\
p_{1}=0.708923 \\
p_{2}=0.006190\end{array}$ \\
\hline
\end{tabular}

The data present as median and intercvartiles range $-M e\left(Q_{1}-Q_{3}\right) \cdot p_{1}$ is $p$-level of difference from control group. $p_{2}$ is $p$-level of difference from group with acute immobilization stress.

Table 2. Hemodynamic parameters of femoral artery blood flow in control group's rats, rats with acute immobilization stress, and rats exposed to terahertz 150.176-150.664 GHz radiation under immobilization stress

\begin{tabular}{|c|c|c|c|c|c|}
\hline \multirow{2}{*}{ Parameters } & \multirow{2}{*}{ Control group } & \multirow{2}{*}{ Immobilization stress } & \multicolumn{3}{|c|}{ Time of radiation exposition under stress } \\
\hline & & & 5 minutes & 15 minutes & 30 minutes \\
\hline Vam, cm/s & $9.67(8.48-10.39)$ & $\begin{array}{c}13.13(12.01-13.91) \\
p_{1}=0.000008\end{array}$ & $\begin{array}{c}9.21(8.18-10.24) \\
p_{1}=0.633364 \\
p_{2}=0.000031\end{array}$ & $\begin{array}{c}10.08(8.61-11.96) \\
p_{1}=0.575511 \\
p_{2}=0.000457\end{array}$ & $\begin{array}{c}9.83(8.87-11.07) \\
p_{1}=0.533830 \\
p_{2}=0.000015\end{array}$ \\
\hline Vas, $\mathrm{cm} / \mathrm{s}$ & $21.17(19.6-22.74)$ & $\begin{array}{c}24.30(23.52-28.23) \\
p_{1}=0.000115\end{array}$ & $\begin{array}{c}21.80(18.82-25.09) \\
p_{1}=0.933886 \\
p_{2}=0.023788\end{array}$ & $\begin{array}{c}22.10(21.17-23.52) \\
p_{1}=0.077932 \\
p_{2}=0.003230\end{array}$ & $\begin{array}{c}21.85(20.38-22.74) \\
p_{1}=0.383733 \\
p_{2}=0.002637\end{array}$ \\
\hline Vad, cm/s & $-1.57(-2.36-0.78)$ & $\begin{array}{c}1.56(0.78-3.92) \\
p_{1}=0.000262\end{array}$ & $\begin{array}{c}-0.63(-3.14-1.56) \\
p_{1}=0.724416 \\
p_{2}=0.003691\end{array}$ & $\begin{array}{c}-0.63(-2.36-2.35) \\
p_{1}=0.648204 \\
p_{2}=0.014397\end{array}$ & $\begin{array}{c}-1.62(-3.14-0.1) \\
p_{1}=0.418618 \\
p_{2}=0.000075\end{array}$ \\
\hline $\mathrm{PG}, \mathrm{mmHg}$ & $0.17(0.14-0.19)$ & $\begin{array}{c}0.23(0.21-0.33) \\
p_{1}=0.000148\end{array}$ & $\begin{array}{c}0.18(0.12-0.25) \\
p_{1}=0.950390 \\
p_{2}=0.017080\end{array}$ & $\begin{array}{c}0.18(0.17-0.21) \\
p_{1}=0.110288 \\
p_{2}=0.003230\end{array}$ & $\begin{array}{c}0.18(0.16-0.19) \\
p_{1}=0.493731 \\
p_{2}=0.001866\end{array}$ \\
\hline
\end{tabular}

Thus, the aim of this work is to study the effects of exposure of albino rats to continuous terahertz radiation with frequencies equal to absorption and emission frequencies of nitrogen oxide (150.176-150.664 GHz) and atmospheric oxygen $(129.0 \pm 0.75 \mathrm{GHz})$ during their immobilization stress on their blood flow rate.

\section{Material and methods}

In order to a find a solution to the aforementioned problem, a group of 120 male non-pedigree albino rats with average weight of 180-220 g was chosen as a test subject. Simulation of hemodynamic disorders was achieved by incurring active immobilization stress.

The animals were exposed to electromagnetic terahertz radiation equal to absorption and emission frequencies of nitrogen oxide (150.176-150.664 GHz) and atmospheric oxygen $(129.0 \pm 0.75 \mathrm{GHz})$. The exposure was done using Orbita, an extremely-high frequency (EHF) therapy apparatus $[19,20]$. The animals with acute immobilization stress received a single dose of radiation for 5,15 and 30 minutes.

Blood flow analysis within abdominal aorta and femoral artery was performed using MM-D-F portable microprocessor-based Doppler ultrasonograph ("Minimax", Russia) [21] and Doppler ultrasonic transducer with $10 \mathrm{MHz}$ working frequency used for ultrasound probing. During the analysis, the following parameters were registered: average linear blood flow velocity (Vam), average linear systolic blood flow velocity (Vas), average linear diastolic blood flow velocity (Vad) and pressure differential (PG).

The studied animals was divided into 5 groups of 15 rats each: $1^{\text {st }}$ group - control group (noninvolved animals), $2^{\text {nd }}$ group - comparison group (animals with acute immobilization stress), $3^{\text {rd }}$, $4^{\text {th }}$ and $5^{\text {th }}$ groups were comprised of animals exposed to terahertz radiation equal to absorption and emission frequencies of nitrogen oxide (150.176-150.664 GHz) for 5, 15 and 30 minutes (respectively) while $6^{\text {th }}, 7^{\text {th }}$ and $8^{\text {th }}$ were comprised of animals exposed to terahertz radiation equal to absorption and emission frequencies of atmospheric oxygen $(129.0 \pm 0.75 \mathrm{GHz})$ for 5,15 and 30 minutes (respectively).

The obtained data were processed with generally accepted parametric and nonparametric methods of statistical analysis using Statistica for Windows v.6.0 software. As Gaussian law was found to be not applicable to majority of obtained data, Mann-Whitney $\mathrm{U}$ test was used for value comparison instead and Fischer's $\mathrm{z}$ test and certainty factor $p$ were calculated on the basis of MannWhitney $U$ test value.

\section{Results}

According to test results, acute immobilization stress leads to statistically-valid (in comparison to control group) changes of hemodynamic parameters including increase of average linear, average linear systolic and average linear diastolic blood flow velocities as well as pressure differential. I.e., in abdominal aorta linear blood flow velocity increased by $26 \%$, systolic blood flow velocity - by $15 \%$, diastolic blood flow velocity - by $75 \%$ and pressure gradient - by $34 \%$, while in femoral artery, linear blood flow velocity increased by $50 \%$, systolic blood flow velocity - by $23 \%$, diastolic blood flow velocity - by $25 \%$ and pressure gradient - by $67 \%$. 
Physiology and Pathophysiology

Table 3. Hemodynamic parameters of abdominal aorta blood flow in control group's rats, rats with acute immobilization stress, and rats exposed to terahertz $129.0 \pm 0.75 \mathrm{GHz}$ radiation under immobilization stress

\begin{tabular}{|c|c|c|c|c|c|}
\hline \multirow{2}{*}{ Parameters } & \multirow{2}{*}{ Control group } & \multirow{2}{*}{ Immobilization stress } & \multicolumn{3}{|c|}{ Time of radiation exposition under stress } \\
\hline & & & 5 minutes & 15 minutes & 30 minutes \\
\hline Vam, cm/s & $15.2(14.04-15.8)$ & $\begin{array}{c}17.7(17.17-20.6) \\
p_{1}=0.000015\end{array}$ & $\begin{array}{c}15.07(12.93-15.29) \\
p_{1}=0.87708 \\
p_{2}=0.000001\end{array}$ & $\begin{array}{c}15.53(13.93-15.98) \\
p_{1}=0.070646 \\
p_{2}=0.000003\end{array}$ & $\begin{array}{c}15.57(14.39-15.86) \\
p_{1}=0.080857 \\
p_{2}=0.000049 \\
\end{array}$ \\
\hline Vas, $\mathrm{cm} / \mathrm{s}$ & $34.5(32.93-35.64)$ & $\begin{array}{c}40.56(35.28-43.91) \\
p_{1}=0.007941\end{array}$ & $\begin{array}{c}32.72(31.36-37.52) \\
\mathrm{p}_{1}=0.173479 \\
\mathrm{p}_{2}=0.000446\end{array}$ & $\begin{array}{c}35.51(32.15-36.85) \\
\mathrm{p}_{1}=0.503580 \\
\mathrm{p}_{2}=0.001875\end{array}$ & $\begin{array}{c}34.9(31.36-37.64) \\
p_{1}=0.071416 \\
p_{2}=0.000246\end{array}$ \\
\hline Vad, $\mathrm{cm} / \mathrm{s}$ & $3.13(0.78-4.7)$ & $\begin{array}{c}3.92(3.13-6.27) \\
p_{1}=9.038089\end{array}$ & $\begin{array}{c}2.35(0.79-3.13) \\
p_{1}=0.118245 \\
p_{2}=0.000182\end{array}$ & $\begin{array}{c}2.31(0.79-2.35) \\
p_{1}=0.95675 \\
p_{2}=0.037626\end{array}$ & $\begin{array}{c}2.35(0.78-3.92) \\
p_{1}=0.526844 \\
p_{2}=0.011364\end{array}$ \\
\hline $\mathrm{PG}, \mathrm{mmHg}$ & $0.46(0.4-0.54)$ & $\begin{array}{c}0.64(0.57-0.73) \\
p_{1}=0.008443\end{array}$ & $\begin{array}{c}0.52(0.38-0.6) \\
p_{1}=0.292906 \\
p_{2}=0.001227 \\
\end{array}$ & $\begin{array}{c}0.48(0.38-0.6) \\
p_{1}=0.704222 \\
p_{2}=0.00303 \\
\end{array}$ & $\begin{array}{c}0.4(0.36-0.54) \\
p_{1}=0.079535 \\
p_{2}=0.000443 \\
\end{array}$ \\
\hline
\end{tabular}

Table 4. Hemodynamic parameters of femoral artery blood flow in control group's rats, rats with acute immobilization stress, and rats exposed to terahertz $129.0 \pm 0.75 \mathrm{GHz}$ radiation under immobilization stress

\begin{tabular}{|c|c|c|c|c|c|}
\hline \multirow{2}{*}{ Paramenetrs } & \multirow{2}{*}{ Control group } & \multirow{2}{*}{ Immobilization stress } & \multicolumn{3}{|c|}{ Time of radiation exposition under stress } \\
\hline & & & 5 minutes & 15 minutes & 30 minutes \\
\hline Vam, cm/s & $9.67(8.48-10.39)$ & $\begin{array}{c}13.13(12.01-13.91) \\
p_{1}=0.000008\end{array}$ & $\begin{array}{c}9.32(9.08-9.76) \\
p_{1}=0.265280 \\
p_{2}=0.001328\end{array}$ & $\begin{array}{c}9.36(9.08-9.84) \\
p_{1}=0.213375 \\
p_{2}=0.000533\end{array}$ & $\begin{array}{c}9.5(9.12-9.84) \\
p_{1}=0.309529 \\
p_{2}=0.010745\end{array}$ \\
\hline Vas, $\mathrm{cm} / \mathrm{s}$ & $21.17(19.6-22.74)$ & $\begin{array}{c}24.30(23.52-28.23) \\
p_{1}=0.000115\end{array}$ & $\begin{array}{c}22.06(21.17-22.74) \\
p_{1}=0.299050 \\
p_{2}=0.000726\end{array}$ & $\begin{array}{c}22.82(21.17-23.52) \\
p_{1}=0.101343 \\
p_{2}=0.071186\end{array}$ & $\begin{array}{c}22.34(21.17-23.52) \\
p_{1}=0.340087 \\
p_{2}=0.014397\end{array}$ \\
\hline Vad, $\mathrm{cm} / \mathrm{s}$ & $-1.57(-2.36-0.78)$ & $\begin{array}{c}1.56(0.78-3.92) \\
p_{1}=0.000262\end{array}$ & $\begin{array}{c}-1.7(-2.36-0.79) \\
p_{1}=0.650439 \\
p_{2}=0.000832\end{array}$ & $\begin{array}{c}-1.56(-2.36-0.79) \\
\mathrm{p}_{1}=0.633364 \\
\mathrm{p}_{2}=0.01359\end{array}$ & $\begin{array}{c}-1.79(-2.75-0.79) \\
p_{1}=0.101343 \\
p_{2}=0.01708\end{array}$ \\
\hline PG, mmHg & $0.17(0.14-0.19)$ & $\begin{array}{c}0.23(0.21-0.33) \\
p_{1}=0.000148\end{array}$ & $\begin{array}{c}0.18(0.17-0.19) \\
\mathrm{p}_{1}=0.354869 \\
\mathrm{p}_{2}=0.000677\end{array}$ & $\begin{array}{c}0.19(0.17-0.21) \\
p_{1}=0.105740 \\
p_{2}=0.067997\end{array}$ & $\begin{array}{c}0.18(0.17-0.21) \\
p_{1}=0.406787 \\
p_{2}=0.010122\end{array}$ \\
\hline
\end{tabular}

Maximal efficiency of continuous exposure of male rats with acute immobilization stress to terahertz radiation equal to absorption and emission frequencies of nitrogen oxide (150.176$150.664 \mathrm{GHz}$ ) was found to be achieved after 5 minutes exposure to terahertz waves. In this case, exposure of male rats with acute immobilization stress to terahertz radiation led to complete recovery from any systematic hemodynamic disorders of abdominal aorta and femoral artery which was evidenced by absence of statistically-valid differences in such hemodynamic parameters as average linear, average linear systolic and average linear diastolic blood flow velocities as well as pressure differential of animals from the studied group in comparison to animals from control group. Continuous exposure of male rats with acute immobilization stress to terahertz radiation for 15 and 30 minutes also led to complete recovery from any systematic hemodynamic disorders in both of the abovementioned great vessels (Tables 1 and 2).

Continuous exposure of male rats with acute immobilization stress to terahertz radiation equal to absorption and emission frequencies of atmospheric oxygen $(129.0 \pm 0.75 \mathrm{GHz})$ for 5 minutes leads to normalization of all studied hemodynamic parameters of abdominal aorta and femoral artery. Further increase of time of exposure to electromagnetic terahertz radiation equal to absorption and emission frequencies of atmospheric oxygen to 15 and 30 minutes does not appear to increase biological effect of terahertz radiation to hemodynamic parameters (Tables 3 and 4).

\section{Discussion}

Active forms of oxygen acts as intermediate agents for positive effect of electromagnetic terahertz radiation equal to absorption and emission frequencies of nitrogen oxide and atmospheric oxygen in cells and body fluids [22]. The said active forms are generated as a result of enzyme-caused changes in hydration of protein molecules and increase of nicotinamide adenine dinucleotide phosphate oxydase, cyclooxygenase and xanthine oxydase activity while concentration of the said enzymes is kept on stationary level. In their turn, active forms of oxygen together with $\mathrm{Ca}^{2+}$ stimulate soluble guanylate cyclase, accumulation of cyclic guanosine monophosphate in endothelial vessel cells and increase of NO-synthase activity which leads to increase of NO generation. This may be one of possible mechanisms of both antistress and vasodilating effect of terahertz radiation equal to absorption and emission frequencies of nitrogen oxide and atmospheric oxygen. Synthesized nitrogen oxide has the ability to form complex compound which can act as a sort of repository in vessel endothelium which is capable of releasing NO, if necessary $[23,24]$.

Nitrogen oxide is a natural regulator of vascular tone, thus causing vasodilating effect [25]. Activation of NO-ergic system also restricts excessive secretion of pituitary-hypothalamic stress hormones (adrenocorticotropic hormone, adrenocorticotropic hormone releasing hormone etc.), blocks secretion of catecholamines by adrenal glands and nerve terminals [26]. Nitrogen oxide also supports stress limiting effect of GABA(gamma-aminobutyric acid)-ergic and opioidergic systems [27] by decreasing concentration of stress-inducing hormones (including adrenaline and adrenocorticotropic hormone), which leads to recovery of platelet aggregation ability disrupted by acute immobilization stress. 
Mechanism of terahertz waves' activity always includes NOsynthase $[28,29]$. NO-synthase can influence formation of active forms of oxygen in endothelial cells by activating nicotinamide adenine dinucleotide phosphate oxydase, thus causing vascular relaxation. I.e. hydrogen peroxide causes endothelium-dependent vessel vasodilation which is mediated by prostaglandins $E_{2}$ and $I_{2}$ [30].

It is known that electromagnetic terahertz radiation equal to absorption and emission frequencies of nitrogen oxide and atmospheric oxygen can replenish decreased nitrite concentration in blood plasma during stress [31,32] which can serve as a indirect indication of normalization of nitrogen oxide generation process and provides an opportunity to normalize endothelial functions.

\section{Conclusion}

The results of this study has shown that according to experimental simulation of hemodynamic disorders during acute immobilization stress, exposure to continuous terahertz radiation with frequencies equal to absorption and emission frequencies of nitrogen oxide (150.176-150.664 GHz) and atmospheric oxygen $(129.0 \pm 0.75 \mathrm{GHz})$ for 5,15 and 30 minutes allows to revert poststress hemodynamic changes in great vessels. This allows using terahertz electromagnetic radiation with frequencies equal to absorption and emission frequencies of nitrogen oxide (150.176$150.664 \mathrm{GHz})$ and atmospheric oxygen $(129.0 \pm 0.75 \mathrm{GHz})$ to treat hemodynamic disorders accompanying some of pathologic diseases.

Conflict of interest: none declared.

\section{Reference}

1. Betsky OV, Lebedeva NN. Application of Low-Intensive Millimeter Waves in Biology and Medicine. Biomeditsynksaya radioelectronika (Biomedical Radioelectronics) 2007; (8-9): 6-25 [Article in Russian].

2. Kirichuk VF. Physiological Effects of Extremely High-Frequency and Terahertz Electromagnetic Waves: The Discoveries of Saratov Medical Scientists. Biomeditsynksaya radioelectronika (Biomedical Radioelectronics) 2007; (2-4): 98-126 [Article in Russian].

3. Kirichuk VF. Achievements of Saratov Scientists in Studying the Influence of Extremely High-Frequency and Terahertz Electromagnetic Waves on Humans and Animals. Millimetrovye Volny $v$ Biologii Meditsyne (Millimeter Waves in Biology and Medicine) 2007; (3): 5-71 [Article in Russian].

4. Kirichuk VF. Results and Perspectives of Experimental Validation of Application of Terahertz Electromagnetic Waves with Frequencies Equal to Frequencies of Molecular Absorption and Emission Spectra (MAES) of Various Cell Metabolites in Clinical Practice. Millimetrovye Volny $v$ Biologii i Meditsyne (Millimeter Waves in Biology and Medicine) 2012; (1): 5-24 [Article in Russian].

5. Kirichuk VF, Golovacheva TV, Parshina SS, et.al. Application of NOtherapy in Clinical Practice. Millimetrovye Volny v Biologii i Meditsyne (Millimeter Waves in Biology and Medicine) 2009; (1-2): 5-21 [Article in Russian].

6. Rothman YS, Gordon JE, Barbe A, Benner D, Bernath PF, Birk M., et al. The HITRAL 2008 Molecular Spectroscopic Database. Journal of Quantitative Spectroscopy and Radioactive Transfer 2009; 110(9-10): 533-572 (doi: 10.1016/j.jqsrt.2009.02.013).

7. Kirichuk VF, Sukhova CV, Antipova ON. Influence of Exposure to Terahertz Electromagnetic Waves with Frequencies Equal to Absorption and Emission Frequencies of Atmospheric Oxygen on Functional Activity of Platelets of Albino Rats with Immobilization Stress. Biomeditsynksaya radioelectronika (Biomedical Radioelectronics) 2008; (12): 41-48 [Article in Russian].
8. Kirichuk VF, Ivanov AN, Antipova ON, Krenitskii AP, Maiborodin AV, Tupikin VD, Betskii OV. Electromagnetic irradiation of the terahertz diapason at nitric oxide frequencies for correction and prevention of disturbances of platelet functional activity in white rats during longterm stress. Cell and Tissue Biology 2007; 1(4): 357-363 (doi: 10.1134/S1990519X07040086).

9. Kirichuk VF, Tsymbal AA, Krenitsky AP, et al. Application of Terahertz Electromagnetic Waves with $129.0 \mathrm{GHz}$ Frequency of Atmospheric Oxygen for Blood Clotting and Fibrinolytic Disorder Treatment. Biomeditsynksaya radioelectronika (Biomedical Radioelectronics) 2009 ; (9): 11-16 [Article in Russian].

10. Tsymbal AA, Kirichuk VF. Changes gas and electrolyte structure of blood under influence terahertz radiations on frequencies nitrogen oxide $150,176-150,664 \mathrm{GHz}$ in the conditions of stress. Patol Fiziol Eksp Ter 2011; (1): 49-51 (PMID: 21688667).

11. Kirichuk VF, Tsymbal AA. Effects of terahertz irradiation at nitric oxide frequencies on intensity of lipoperoxidation and antioxidant properties of the blood under stress conditions. Bull Exp Biol Med 2009; 148(2): 200-203 (PMID: 20027328).

12. Kirichuk VF, Tsymbal AA. Use of Terahertz Irradiation at the Frequencies of Nitric Oxide for Correction of the Antioxidant Properties of the Blood and Lipid Peroxidation in Stress. Neuroscience and Behavioral Physiology 2011; 41(5): 495-499 (DOI: 10.1007/s11055-011-9443-4).

13. Kirichuk VF, Tsymbal AA. Use of terahertz electromagnetic radiation at nitric oxide frequencies for the correction of thyroid functional state during stress. Vestn Ross Akad Med Nauk (Annals of the Russian Academy of Medical Sciences) 2010; (4): 37-40 (PMID: 20540354).

14. Tsymbal AA, Kirichuk VF, Krenitsky AP. Recovery of Primary Indices of Metabolic Status by Exposure to Terahertz Electromagnetic Waves with Frequencies of Nitrogen Oxide $(150.176-150.64 \mathrm{GHz})$ as a Result of Expirement. Biomeditsynksaya radioelectronika (Biomedical Radioelectronics) 2011; (1): 30-35 [Article in Russian].

15. Tsymbal AA, Kirichuk VF, Antipova ON. Changes of Concentration of Adrenocorticotropic Hormone in Blood of Experimental Animals as a Result of Exposure to Terahertz Electromagnetic Waves with 129.0 $\mathrm{GHz}$ Frequency of Atmospheric Oxygen During Acute and Continuous Stress. Biomeditsynksaya radioelectronika (Biomedical Radioelectronics) 2011; (8): 23-29 [Article in Russian].

16. Kirichuk VF, Ivanov AN, Andronov EV. Influence of Terahertz Electromagnetic Waves with Frequencies of Nitrogen Oxide on Post Stress Disorders of Carbohydrate Component and Activity of Platelet Glycoprotein Receptors. Biomeditsynksaya radioelectronika (Biomedical Radioelectronics) 2010; (5): 39-46 [Article in Russian].

17. Kirichuk VF, Ivanov AN, Kiriyazi TS. Changes in Functional State of Endothelium and Peripheral Perfusion of Albino Rats with Acute Immobilization Stress as a Result of Exposure to Terahertz Electromagnetic Waves with Frequencies of Nitrogen Oxide. Biomeditsynksaya radioelectronika (Biomedical Radioelectronics) 2010; (12): 30-37 [Article in Russian].

18. Kirichuk VF, Ivanov AN, Kirijazi TS. Correction of Microcirculatory Disturbances with Terahertz Electromagnetic Radiation at Nitric Oxide Frequencies in Albino Rats under Conditions of Acute Stress. Bulletin of Experimental Biology and Medicine 2011; 151(3): 288-291 (doi: 10.1007/s10517-011-1311-2).

19. Tsymbal AA, Kirichuk VF. Apparatus for Extremely-high Frequency (EHF) Electromagnetic Wave Therapy. Med Tekh 2011; (3): 42-46 [Article in Russian]

20. Kirichuk VF, Tsymbal AA. Use of Terahertz Electromagnetic Waves for Correcting Hemostasis Functions. Biomedical Engineering 2010; 44 (1): 11-14 (doi: 10.1007/s10527-010-9145-1).

21. Domashenko RA, Andozhskaya YuS, Plotkin GL. Assessing the impact on Clexane microcirculation in patients with Doppler device Minimax. Regionarnoe Krovoobrashchenie i Mikrotsirkulyatsya (Regional Circulation and Microcirculation) 2002; (4): 76-78 [Article in Russian]

22. Potselueva MM, Pustovidko AV, Evtodienko YuV. The formation of reactive oxygen species in aqueous solution under the influence of 
electromagnetic radiation EHF. Doklady Academii Nauk 1998; (3): 415418 [Article in Russian].

23. 23. Pshennikova M.G., Smirin B.V., Bondarenko O.N. Deposition of nitrogen oxide in rats of different genetic lines and its role in the antistress effect of adaptation to hypoxia. Russian Journal of Physiology n.a. N.M. Sechenov 2000; 86(2): 174-181 [Article in Russian].

24. Kirichuck VF, Velikanova TS, Ivanov AN. Hemodynamic Changes Induced by Preventive Exposure to Terahertz Radiation at a Frequency Range Corresponding to Molecular Emission and Absorption Spectrum of Nitric Oxide in Animals under Conditions of Acute Stress. Bull Exp Biol Med 2010; 151(2): 186-189 (PMID: 22238746) (doi: 10.1007/s10517-011-1285-0).

25. Kirichuk VF, Tsymbal AA. Effects of terahertz radiation at atmospheric oxygen frequency of $129 \mathrm{GHz}$ on blood nitrite concentrations under conditions of different types of stress against the background of administration of nonselective inhibitor of constitutive NO-synthases. Bull Exp Biol Med 2012; 152(4): 435-438 (PMID: 22803105) (doi: 10.1007/s10517-012-1547-5).

26. Kirichuck VF, Ivanov AN, Kulapina EG, Krenickiy AP, Mayborodin AV. Effect of Terahertz Electromagnetic Irradiation at Nitric Oxide Frequencies on Concentration of Nitrites in Blood Serum of Albino Rats under Conditions of Immobilization Stress. Bull Exp Biol Med 2011; 149(2): 174-176 (PMID: 21113484) (doi: 10.1007/s10517-010-0900-9).

27. Kirichuk VF, Ivanov AN, Velikanova TS, et.al. Influence of endothelial NO shyntase inhibitor L-Name and influence of electromagnetic terahertz waves at frequency of molecular spectrum of radiation and absorption of nitric oxide 150,176-150,664 GHz on system hemodynamic in mail rats subjected in conditions of immobilization stress. Biomeditsynksaya radioelectronika (Biomedical Radioelectronics) 2011; (1): 19-24 [Article in Russian].

28. Kirichuk VF, Ivanov AN, Kiriyazi TS. The role of NO-synthase in the reaction of endothelium and changes in peripheral perfusion under the influence of electromagnetic terahertz waves at frequencies of nitric oxide in albino rats in a state of acute stress. Biomeditsynksaya radioelectronika (Biomedical Radioelectronics) 2011; (8): 12-18 [Article in Russian].

29. Ignarro L, Cirino G, Casini A, Napoli C. Nitric oxide as a signating molecule in the vascular system: an overview. J Cardiovasc Pharmacol 1999; 34: 879-886 (PMID: 10598133).

30. Addicks K, Bloch W, Feelisch M. Nitric oxide modulates sympathetic neurotransmission at the prejunctional level. Microsc Res Tech 1994; 29(2): 161-168 (PMID: 7529070).

31. Armstead WM. Nitric oxide contributes to opioid release from glia during hypoxia. Brain Res 1998; 813(2): 398-401 (PMID: 9838202) (doi: 10.1016/S0006-8993(98)01022-1).

32. Naesh O, Haedersdal C, Hindberg I, Trap-Jensen J. Platelet activation in mental stress. Clin Phisiol 1993; 13(3): 299 - 307 (PMID: 8390927).

\section{Authors:}

Vyacheslav F. Kirichuk - MD, D.Sc., Professor, Honored Scientist of Russia, Head of Department of Normal Physiology n.a. I.A. Chuevsky, Saratov State Medical University n.a. V.I. Razumovsky, Saratov, Russia;

Vitaly V. Velikanov - MD, Postgraduate, Department of Normal Physiology n.a. I.A. Chuevsky, Saratov State Medical University n.a. V.I. Razumovsky, Saratov, Russia;

Tatyana S. Velikanova - MD, PhD, Assistant, Department of Normal Physiology n.a. I.A. Chuevsky, Saratov State Medical University n.a. V.I. Razumovsky, Saratov, Russia;

Olga N. Antipova - MD, D.Sc., Associate Professor, Department of Normal Physiology n.a. I.A. Chuevsky, Saratov State Medical University n.a. V.I. Razumovsky, Saratov, Russia;

Evgeny V. Andronov - MD, D.Sc., Professor, Department of Normal Physiology n.a. I.A. Chuevsky, Saratov State Medical University n.a. V.I. Razumovsky, Saratov, Russia;

Alexey N. Ivanov - MD, PhD, Associate Professor, Department of Normal Physiology n.a. I.A. Chuevsky, Saratov State Medical University n.a. V.I. Razumovsky, Saratov, Russia;
Svetlana S. Parshina - MD, D.Sc., Professor, Department of Therapy, Faculty training and retraining of specialits, Saratov State Medical University n.a. V.I. Razumovsky, Saratov, Russia;

Natalia E. Babichenko - MD, PhD, Associate Professor, Department of Normal Physiology n.a. I.A. Chuevsky, Saratov State Medical University n.a. V.I. Razumovsky, Saratov, Russia;

Tatyana S. Kiriyazi - PhD, Senior Lecturer, Department of Normal Physiology n.a. I.A. Chuevsky, Saratov State Medical University n.a. V.I. Razumovsky, Saratov, Russia;

Elena V. Ponukalina - MD, D.Sc., Professor, Department of Normal Physiology n.a. I.A. Chuevsky, Saratov State Medical University n.a. V.I. Razumovsky, Saratov, Russia;

Irina V. Smyshlyaeva - MD, PhD, Associate Professor, Department of Normal Physiology n.a. I.A. Chuevsky, Saratov State Medical University n.a. V.I. Razumovsky, Saratov, Russia;

Liliana K. Tokaeva - MD, D.Sc., Professor, Department of Normal Physiology n.a. I.A. Chuevsky, Saratov State Medical University n.a. V.I. Razumovsky, Saratov, Russia;

Alexander A. Tsymbal - MD, PhD, Associate Professor, Department of Normal Physiology n.a. I.A. Chuevsky, Saratov State Medical University n.a. V.I. Razumovsky, Saratov, Russia. 